\title{
Incidents Of Ogling In Kaduna Town
}

\author{
A.N. Sankey \\ Dept. Of Geography Kaduna State University
}

\begin{abstract}
This study examines the activities of Ogling in Kaduna town. It investigates those involved and the effect of Ogling. This is achieved through administration of questionnaire and interview of selected drivers. The people in Kaduna are very much aware of the major causes of accidents but they have less consideration for Ogling The study has revealed that over $70 \%$ accept they have been totally attracted by pedestrians'. The attraction seems to be more during the hot season which is put a nearly50\%. Probably because of heat people tend to wear light clothes. Nearly one half of respondents wish to see the person that attracts them again, while just over one half are not interested in seeing that person again. In Kaduna, because drivers cannot take their eyes Off beautiful women//hot guys, $49.5 \%$ claim they have crashed in to the car in front of them while ogling About one quarter of those who have accidents careless on the experience while over $70 \%$ did not like the experience. But all of the respondents say they will not tell their spouses the real cause of the accident and over three quarters indicate they cannot stop ogling. In general, the ratio of men vs women ogling is 3:2. The men blame it on the women's provocative dressing. Thus, there is every need to imbibe decent code of dressing so that men who admitted been the major actors of ogling, will look less
\end{abstract}

\section{Introduction}

The increasing deaths experienced in Nigeria from road traffic accidents are a public health challenge that requires pro-active attention. For instance, Nzegwu and Nzegwu (2007) and Hula (2010) have blamed the major causes of accidents on over speeding, recklessness, alcohol, poor road conditions and mechanical faults.

Most of the causes of the accidents are blamed on human factors. However, there is an aspect of human factor that is hardly mentioned which is ogling and leering. The Oxford advanced learners Dictionary defines the verb form of ogling as to look hard at somebody in an offensive way usually showing sexual interest. On the other hand, the Riverside Webster 11 New College Dictionary feels ogle is to stare at in an impertinent, provocative manner, or flirtatiously that is lustfully. Both have a common factor of unrestrained sexual desire. According to a commentary in the Nation Daily Newspaper, (2012) a columnist revealed that nearly one million crashes happen every year because of drivers' attitude of ogling pedestrians while behind the wheels. This study may not give the figure of actual crashes that have occurred as result of ogling in Kaduna town but it has painted a graphical picture that a daily encounter on the street of Kaduna town is becoming worrisome Both men and women take turn to look at beautiful women or handsome guys.

\section{Data Collection and Analysis procedure}

The data of this study are obtained largely from questionnaire based interviews. For the purpose of this research, it is deemed very pertinent to have personal contact with respondents in order to obtain vital behavioral information. The primary data was drawn from questionnaires structured for the purpose of obtaining information on the extent of involvement of drivers in ogling, their experience and who are involved in terms of sex. The work or study identified some important recreational joints, motor parks and offices were questionnaires were administered on people who alleged to be drivers or owned a car. Thirdly, interview was also conducted to elicit information from people (drivers) knew that their actions were dangerous to other road users and to themselves. English and Hausa language was employed to explain the content of the questionnaire.

The researcher with the help of a trained assistant, took three days to administered a total of 103 questionnaires and purposefully interviewed few people.

The responses of respondents were counted to generate frequency which was converted into percentages to help in giving a graphical summary distribution of responses which enabled the researcher to give a pictorial graph of findings using the excel spreadsheet and SPSS as a tool for analysis. Information from interview was given a descriptive interpretation. Based on these, data for this study is made up of both quantitative and qualitative attributes.

\section{Result}

Table 1 reveals that more men served as respondents in the study, represented by $60.2 \%$ and $39.8 \%$ respectively with a ratio 3:2.Atotal of 103 questionnaires was administered to 62 men and 41 women. In terms of level of involvement in ogling, men seem to be the major actors $74 \%$ as against the women $26 \%$.Involved. 
Investigation shows that $65.0 \%$ of the respondents affirmed that the person who attracted them was walking or standing while $35 \%$ said that the person with the centrifugal attraction was driving as illustrated in table 3.

The respondents identifies two seasons for ogling, but claims that ogling is more during the heat period as over $60 \%$ attested or claim heat while only less than $5 \%$ sees cold season for ogling. The rest people could not link ogling to any season. The researcher wanted to know whether the respondents were attracted by the person they saw. $74.8 \%$ yes and No $25.2 \%$. Furthermore, respondents were asked to indicate whether they will like to See the person that attracted the again. $49.5 \%$ respondents said yes while 50.5\% said no. In addition, the respondents were asked to say if they had any experience while looking at an opposite sex. 49.5\% acknowledged of hitting the vehicle in front of them, 26.2\% said they hit an object (pole or road pavement) and $24.3 \%$ said they nearly crashed the car.

As for whether they like the experience, $24.3 \%$ felt not worried while $75.7 \%$ did not like the experience. Since ogling is a potential cause of accidents, respondents were asked to comment whether they will tell their spouses the real cause of the accident if there was one. Shockingly, neither the male nor the female accept to tell the truth. It was capital NO represented by $100 \%$.

Thus, the study reveals that ogling is a daily act among people in Kaduna but less consideration has been given and to it as a cause of accident especially in Nigeria. A respondent feels that ogling is natural among men because the way to a man's heart is the eye also men love with their eyes while women love with their ears. This is buttressed by over $60 \%$ of the men respondents that they cannot do without ogling.

The study has also discovered that men tend to look at the opposite sex more during the hot season and less in the wet season. This could be attributed to the fact that men and women wear light/ less clothing which at times exposes sensitive parts of their body. But people tend to thatch themselves with clothes in the wet and cold season, thus looking less attractive.

So, exposing sensitive body parts can be said to provocative or indecent and this could lead to rape. Thus, Glamour (2012) ... I want to crave the indulgence of ladies to limit, if they cannot totally avoid showing off sensitive parts of their bodies. Our men should also control themselves and look less when they come across females who are improperly dress. The study further reveals that men are unable to just throw their eyes off beautiful women even though the women accepted same, but are more timid. A respondent proudly claim that whether beautiful or not, he cannot just get his eyes off a voluptuous woman, as such he will like to see such a person again and again. Even though the study does not provide any statistics of accidents as a result of ogling, more than one half of the sampled population acknowledged hitting an object, while about a quarter indicates they nearly crash the car. Few among those who have had accidents do not regret the experience. Even though men and women admit to ogling, all the respondents claim they will not tell their spouses that the real cause of the accident is ogling, and they will ogle again, while other people claims they are more careful after their first experience.

In Nigeria, most accidents are either blamed on human or mechanical factors. Due to our driving attitude in this part of the world, more study needs to be conducted on the human factor as a cause of accident. As such there is a need for comprehensive and analytical study on ogling and leering in Nigerian societies.

In conclusion, ogling is admitted as extreme attention drive by provocative dressing,that exposes vital and sensitive parts of the body that the ordinary human person cannot afford to ignore. Thus, the types of dressing do attract both sexes, but men are more attracted by women. Hence, this study evolves the implications especially as it relates to cause of accidents in our society as unprecedented. To mitigate vehicular accident therefore, socio- cultural values and norms that will prevent unwholesome dressing particularly by young ladies must be invoked

\section{References}

[1]. Hula, M.A.K. (2010) Intra-Urban Traffic Accidents Rate among Commercial Motorcyclists in Makurdi

[2]. Urban: It's impact on the quality of life of the people. In Ogidiolu, A, Muba, S.D. and Ifatihehin, O.O Contemporary issues in infrastructural development and management in Nigeria. Department of Geography and planning Kogi State University Anyigba Pp.9-20.

[3]. The Nation Newspaper Friday, September $7^{\text {th }}$ (2012) “ comments : Fatal Attraction” Vintage Press Limited Lagos P.19

[4]. New $7^{\text {th }}$ Edition Oxford Advanced Learners Dictionary

[5]. Nzegwu, M.A. and Nzegwu, C.O (2007) Review of Causes of Road Traffic Accidents in Benin City, Nigeria. A 1 Year Study, August 2003 - July 2004.Journal compilations Australasian college of Emergency Medicine and Australasian Society for emergency medicine P. 77-78.

[6]. Riverside Webstar 11 New College Dictionary

[7]. Supergal, O (2013.pp32-33 ) Men should look less on Ladies who dress to provoke.African Newspapers of Nigeria plc lagos 
FREQUENCY TABLE

TABLE 1: SEX

\begin{tabular}{|l|l|l|l|l|}
\hline & FREQUENCY & PERCENTAGE & $\begin{array}{l}\text { VALID } \\
\text { PERCENTAGE }\end{array}$ & $\begin{array}{l}\text { CUMULATIVE } \\
\text { PERCENTAGE }\end{array}$ \\
\hline VALID MALE & 62 & 60.2 & 60.2 & 60.2 \\
\hline FEMALE & 41 & 39.8 & 39.8 & 100.0 \\
\hline TOTAL & 103 & 100.0 & 100.0 & \\
\hline
\end{tabular}

TABLE 2: Have you ever looked at an opposite sex while driving?

\begin{tabular}{|l|l|l|l|l|}
\hline & Frequency & Percentage & Valid percentage & $\begin{array}{l}\text { Cumulative } \\
\text { percentage }\end{array}$ \\
\hline Valid yes & 76 & 73.8 & 73.8 & 73.8 \\
\hline no & 27 & 26.2 & 26.2 & 100.0 \\
\hline Total & 103 & 100.0 & 100.0 & \\
\hline
\end{tabular}

Table 3:

was he/she walking or driving?

\begin{tabular}{|c|l|l|l|l|}
\hline & Frequency & Percentage & $\begin{array}{l}\text { Valid } \\
\text { percentage }\end{array}$ & $\begin{array}{l}\text { Cumulative } \\
\text { frequency }\end{array}$ \\
\hline Valid walking & 67 & 65.0 & 65.0 & 65.0 \\
\hline driving & 36 & 35.0 & 35.0 & 100.0 \\
\hline & & 100.0 & 100.0 & \\
\hline
\end{tabular}

Table 4: Season

\begin{tabular}{|c|l|l|l|l|}
\hline & Frequency & Percentage & Valid percentage & $\begin{array}{l}\text { Cumulative } \\
\text { frequency }\end{array}$ \\
\hline Valid hot season & 51 & 49.5 & 49.5 & 52.4 \\
\hline Cold season & 3 & 2.9 & 2.9 & 2.9 \\
\hline Can't remember the season & 49 & 47.6 & 47.6 & 100.0 \\
\hline & 103 & 100.0 & 100.0 & \\
\hline
\end{tabular}

Table 5:

were you attracted by the person you saw?

\begin{tabular}{|c|l|l|l|l|}
\hline & Frequency & Percentage & Valid percentage & $\begin{array}{l}\text { Cumulative } \\
\text { percentage }\end{array}$ \\
\hline Valid yes & 77 & 74.8 & 74.8 & 74.8 \\
\hline No & 26 & 25.2 & 25.2 & 100.0 \\
\hline total & 103 & 100.0 & 100.0 & \\
\hline
\end{tabular}

Table 6: did you wish you could see the person again?

\begin{tabular}{|c|l|l|l|l|}
\hline & Frequency & Percentage & Valid percentage & $\begin{array}{l}\text { Cumulative } \\
\text { percentage }\end{array}$ \\
\hline Valid yes & 51 & 49.5 & 49.5 & 49.5 \\
\hline no & 52 & 50.5 & 50.5 & 100.0 \\
\hline Total & 103 & 100.0 & 100.0 & \\
\hline
\end{tabular}

Table 7: which of these did you experience while looking at the opposite sex?

\begin{tabular}{|l|l|l|l|l|}
\hline & Frequency & Percentage & Valid percentage & $\begin{array}{l}\text { Cumulative } \\
\text { percentage }\end{array}$ \\
\hline $\begin{array}{l}\text { Valid smashed } \\
\text { the car in front of } \\
\text { me }\end{array}$ & 51 & 49.5 & 49.5 & 49.5 \\
\hline $\begin{array}{l}\text { Crashed to a pole } \\
\text { or road pavement }\end{array}$ & 27 & 26.2 & 26.2 & 75.6 \\
\hline $\begin{array}{l}\text { Nearly crashed } \\
\text { the car }\end{array}$ & 25 & 24.3 & 24.3 & \\
\hline total & 103 & 100.0 & 100.0 & \\
\hline
\end{tabular}


Table 8: did you like the experience?

\begin{tabular}{|c|l|l|l|l|}
\hline & Frequency & Percentage & $\begin{array}{l}\text { Valid } \\
\text { percentage }\end{array}$ & $\begin{array}{l}\text { Cumulative } \\
\text { percentage }\end{array}$ \\
\hline Valid yes & 25 & 24.3 & 24.3 & 24.3 \\
\hline No & 78 & 75.7 & 75.7 & 100.0 \\
\hline total & 103 & 100.0 & 100.0 & \\
\hline
\end{tabular}

Table 9: if there was an accident would you tell your wife/husband the real cause of the accident?

\begin{tabular}{|l|l|l|l|l|}
\hline & Frequency & Percentage & Valid percentage & $\begin{array}{l}\text { Cumulative } \\
\text { percentage }\end{array}$ \\
\hline Valid no & 103 & 100.0 & 100.0 & 100.0 \\
\hline
\end{tabular}

Table 10: after that experience, have you stared at the opposite sex again when driving?

\begin{tabular}{|c|l|l|l|l|}
\hline & Frequency & Percentage & Valid percentage & $\begin{array}{l}\text { Cumulative } \\
\text { percentage }\end{array}$ \\
\hline Valid yes & 78 & 75.7 & 75.7 & 75.7 \\
\hline No & 25 & 24.3 & 24.3 & 100.0 \\
\hline total & 103 & 100.0 & 100.0 & \\
\hline
\end{tabular}

